\title{
Effect of Liquidity Management Practices on Profitability of Manufacturing Industry in Kenya
}

\author{
James Ndirangu Kung'u \\ Laikipia University, Department of Commerce, School of Business, Kenya
}

\begin{abstract}
Industrial firms require liquid cash for smooth operations. Failure to convert current assets into liquid cash can force a profitable firm into liquidation. The purpose of this study was to determine the effect of liquidity management practices on profitability of industrial firms in Kenya. The study was explained by two cash management models; Baumol's cash management model and Miller - Orr cash management model. Correlational research design was adopted. Two types of data were collected. Primary data was collected through the use of a questionnaire and secondary data through the use of a record survey sheet. Stratified random sampling technique was used to determine the sample size. Data analysis was through descriptive and inferential data analysis. The inferential data analysis, Pearson's correlation, regression and ANOVA analysis were applied. The results of the analysis indicated that the correlation coefficient between liquidity cash management and profitability was 0.711 at 0.01 significant level. This showed a positive and significant relationship between liquidity management practices and profitability of industrial firms. $R^{2}$ value was 0.5055 which means that $50.55 \%$ of the corresponding variation in profitability can be explained by change in liquidity management practices. The rest $49.45 \%$ can be explained by other factors that are not in the model. The ANOVA results on liquidity management practices and profitability had an F-value of 90.677 which was significant with a $P$ - value $=0.000$ meaning that the overall model was significant in the prediction of profitability in industrial firms in Kenya. It is recommended that the finance managers should establish optimal cash targets, lower and upper cash limits in their industrial firms. They should also invest excess cash into productive assets.
\end{abstract}

Keywords: Baumol's Model, Industrial Firms, Liquidity, Miller-Orr Model, Profitability)

\section{Introduction}

Industrial firms need cash and other liquid assets or current assets to pay their bills or current liabilities as they fall due. If a company has insufficient current assets in relation to its current liabilities, it might be forced into liquidation. Liquidity problems can arise from the failure to convert current assets into cash in a timely manner or from excessive bad debt losses. Therefore, liquidity is an important aspect that conveys a good picture about the ability of the firm to generate cash and pay short term liabilities and long term debts as they fall due (Award \& Al-Ewesat, 2012). According to Cornett, Adair and Nofsinger (2009) liquidity ratio is a tool that is used to measure the relationship between a firm's liquid or current assets and its current liabilities as they fall due. Hence, Liquidity ratios are computed to compare the relationship between various groups of current assets and current liabilities to measure the liquidity position of a firm. Saleemi (1993) argues that liquidity ratios help in ascertaining the effectiveness of the working capital management. Current, quick and cash ratios are the three types of liquidity ratios that are normally computed.

Current ratio compares total current assets to total current liabilities. Current assets are the assets which can be converted into cash within an accounting year and include short term securities, debtors, bills receivable and stock (Pandey, 2008). Current liabilities on the other hand, are claims from outsiders which are expected to mature for payment within an accounting year and include creditors, bills payable and outstanding expenses (Pandey, 2008). Current ratio is intended to indicate whether short term assets are sufficient to meet short term liabilities.

Cornett et al. (2009) assert that current ratio measures the shilling of current assets available to pay each shilling of current liabilities. Wood and Sangster (1999) argue that current ratio is so sector dependent as to be incapable of being defined as generally best. They suggest factors that need to be considered when calculating this ratio. The factors are put in a form of questions. First, what is the norm in this industrial sector? Secondly, is this company significantly above or below that norm? And finally, if so, can this be justified after an analysis of the nature of these assets and liabilities, and of the reasons for the amounts of each held? The ratio when calculated is expressed as either a ratio to 1 , with current liabilities being set to 1 , or as a number of times representing the relative size of the amount of total current assets compared with current liabilities. The most acceptable current ratio is $2: 1$. Current ratio is computed by dividing current assets with current liabilities. Current ratio indicates the liquidity position of a company. It measures the ability of a company to meet its current liabilities as they fall due. If a company has insufficient current assets in relation to its current liabilities, 
it might be unable to meet its commitments and be forced into liquidation (Saleemi, 1993). Quick ratio measures the shillings of more liquid assets, that is, cash and marketable securities and accounts receivable that are available to pay each shilling of current liabilities. An asset is liquid if it can be converted into cash immediately or reasonably soon without a loss of value (Pandey, 2008). Quick ratio is found out by dividing quick assets by current liabilities. Inventories are considered to be less liquid. Inventories normally require some time for realizing into cash; their value has a tendency to fluctuate (Pandey, 2008). Quick assets ratio measures firm's ability to pay off short term obligations without relying on inventory sales (Cornett et al., 2009). Quick ratio is computed by getting the sum of accounts receivable, cash and marketable securities and dividing the results by current liabilities. The most ideal ratio is $1: 1$.

Cash management is the process of planning and controlling cash flows into and out of business, cash flows within the business, and cash balances held by a business at a point in time (Pandey, 2008). Naser, Nuseibel and Al-Hadeya (2013) see cash management as the process of ensuring that enough cash is available to meet the running expenses of a business and aims at reducing the cost of holding cash. Efficient cash management involves the determination of the optimal cash to hold by considering the trade-off between the opportunity cost of holding too much cash and the trading cost of holding too little cash (Ross, Westerfield, Jaffe \& Jordan, 2008). Atrill (2006) asserts that there is a need for careful planning and monitoring of cash flows over time so as to determine the optimal cash to hold. The Null Hypothesis of this study was $\mathrm{H}_{01}$ : Liquidity Management Practices have no significant influence on Profitability of Industrial Firms in Kenya

\section{Literature Review}

Liquidity management can be explained by two cash management models; baumol's cash management model and Miller - Orr cash management model. The model was designed to minimize the sum of opportunity cost associated with holding cash and trading costs associated with converting other to cash. The procedure is very similar to the economical order quantity (EOQ) model for inventory size but it deals with different variables. It assumes that the firm holds a portfolio of marketable securities which can easily be converted into cash (Baumol, 1952). According to this model, cash is assumed to start from a replenishment level, C, and then declines smoothly to a value zero. When cash declines to zero, it can be immediately replenished by selling another C worth of marketable securities, for which the firm has to pay a trading cost of F (Cornett et al., 2009).

In Baumol model, the financial manager has to decide on the repartition of liquid funds between cash and marketable securities (Pandey, 2008). Once again, there is a trade-off which constitutes the basis for the calculation. Yet, this trade-off is related to the opportunity costs of holding cash which increase along with the cash level and the trading costs which are incurred with every transaction and which decrease when the cash level increases (Cornett et al., 2009).

The opportunity costs represent the interest forgone for funds which are held in cash instead of being invested. The trading costs correspond to fixed costs which are incurred when a company decides to either buy or sell marketable securities (Pandey, 2008). If a company decides to maintain a low cash level it will have to carry out many transactions leading to high trading costs but low opportunity costs because there are little idle cash funds. If it maintains a high level of cash, the firm's opportunity costs will be higher due to the relatively large amount of un-invested cash but the trading costs will decrease since only a few transactions will be necessary (Pandey, 2008).

Baumol's cash management model has three assumptions; first, the firm uses cash at a steady predictable rate, cash flows from operations also occur at a steady state and finally the net cash out flow occur at a steady state. Under these assumptions the model can be stated as follows:

$C^{*}=\sqrt{2 \mathrm{TF} / \mathrm{i}}$

Where: $\mathrm{C}=$ is the optimal cash replenishment level

$\mathrm{T}=$ is the annual demand for cash

$\mathrm{F}=$ is the trading cost per transaction

$\mathrm{i}=$ is the interest rate on marketable securities

Hence, using this formula an organization can determine the optimal cash replenishment level. Despite the fact that Baumol's cash management is an important tool in management, it suffers from a number of short comings; first, the model assumes that the firm has a constant, perfectly disbursement rate for cash. In reality, disbursement rates are much more variable and unpredictable; secondly, the model assumes that no cash will come in during the period in question. Since most firms hope to make more money than they pay out, and usually have cash inflows at all times, this assumption is obviously at odd with what we see. Finally, the model does not allow for any safety stock of extra cash to buffer the firm against unexpectedly high demand for cash (Cornett et al., 2009). 
Miller - Orr cash management model was derived by Morton Miller and Daniel Orr (Cornett et al., 2009 ) in an attempt to produce a more realistic approach to cash management over Baumol's model. The model manages to achieve a reasonable degree of realism while not being too elaborate. It assumes that the net cash flows are uniformly distributed with zero value of mean and standard deviation. The model uses some information to derive a mathematical formula. First, the lower control limit, L, second, the trading cost for marketable securities per transaction, $\mathrm{F}$, third, the standard deviation in net daily cash flows, $\sigma$, and finally, the daily interest rate on marketable securities, $i_{\text {day. }}$ The model is given by the pair of mathematical notion:

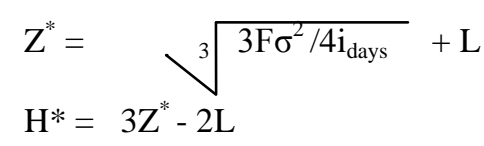

The firm determines L, and the firm can set it to a non-zero number to recognize the use of safety stock. $Z^{*}$ is the optimal cash return point and is the replenishment level to which cash is replenished when the cash level hits $\mathrm{L} . \mathrm{H}^{*}$ is the upper limit for cash balances and cash balances are brought down to $\mathrm{Z}^{*}$ when cash balance hits $\mathrm{H}^{*}$ (Cornett et al., 2009).

The firm sets the lower limit as per its requirements of maintaining cash balance and upper limit as the control limit as well as its return point. If cash balance reaches the upper limit, the firm buys sufficient securities to return the cash balance to a normal level called the return point. When cash balances reach a lower limit, the firm sells securities to bring the balance back to return point (Pandey, 2008).

O'Donnell and Goldberger (1964) assert that the adequacy of cash and current assets together with their effective handling virtually determines the survival or demise of a concern. An enterprise should maintain adequate working capital for its smooth functioning. If materials are recklessly purchased, it will result in dormant slow moving and absolute inventory. However, inadequate amount of inventory will result to stock outs and interruption in operations (O’Donnell \& Goldberger, 1964). Cash must also be maintained at an ideal level. It may also result to increased cost due to mishandling, waste and theft. Too much or inadequate level of cash balances mean cash is not properly utilized. Inadequate level of cash balance for example can lead to stoppage in business operations (Padachi, 2006). A company may be profitable but with no liquid cash which can result to operations interruptions. The company can also be forced into winding up by its creditors.

A study by Kwame (2007) established that the setting up of a cash balance policy ensures prudent cash budgeting and investment of surplus cash. These findings agreed with the findings of Kotut (2003) who established that cash budgeting is useful in planning for shortage and surplus of cash and has an effect on the financial performance of the firms. Ross et al. (2008) assert that reducing the time cash is tied up in the operating cycle improves a business's profitability and market value. This further supports the significance of efficient cash management practices in improving business performance. The objective of the study was to establish whether liquidity management practices influence profitability of manufacturing industry in Kenya.

Scholars have different opinions on the relationship between liquidity ratios and profitability. According to studies carried out by (Radhika \& Azhagaiah, 2012; Singh \& Pandey, 2008) current ratio has a high significant positive co-efficient with profitability while Eljelly (2004) found that the relationship between current ratio and profitability is negative. Smith and Begemann (1997) found insignificant association between current ratio and profitability. Amalendu and Sri (2011) in their study on liquidity management on profitability in steel industries in India used current ratio and absolute liquidity ratio as measures of liquidity. They found a positive relationship between liquidity and profitability. Nyabwanga, Ojera, Lumumba, Odondo and Otieno (2012) in their study on effects of working capital management practices on financial performance found that small scale enterprises financial performance was positively related to efficiency of cash management. Finally, Radhika and Azhagaiah (2012) found a negative association between quick ratio and profitability.

\section{Methodology}

This study adopted a correlational research design. Two types of data were collected. Primary data was collected through the use of a questionnaire and secondary data through the use of a record survey sheet. A sample of 71 firms was determined through stratified random sampling technique. Data analysis was done through descriptively and quantitatively. In descriptive analysis frequency and means of responses were determined. Correlation, regression and ANOVA were the quantitative tools that were used to analysis the data.

\section{Results And Discussion}

The objective of the study was to establish whether liquidity management practices influence profitability of manufacturing firms in Kenya. The objective was tested through eight (8) composite measures on a scaled questionnaire. The findings were presented in table 1 below which shows the frequencies of responses and mean on the effect of liquidity management practices on profitability. 
Table 1: Liquidity Management Practices Descriptive Results

\begin{tabular}{|l|l|l|l|l|l|l|l|}
\hline & Statement & $1 \%$ & $2 \%$ & $3 \%$ & $4 \%$ & $5 \%$ & $\begin{array}{l}\text { Likert } \\
\text { Mean }\end{array}$ \\
\hline 1 & $\begin{array}{l}\text { The current assets are maintained at a higher level than } \\
\text { the current liabilities }\end{array}$ & 0 & 2.8 & 7.0 & 47.9 & 42.3 & 4.30 \\
\hline 2 & $\begin{array}{l}\text { The inventories constitute a large portion of the total } \\
\text { current assets }\end{array}$ & 0 & 11.3 & 5.6 & 53.5 & 29.6 & 4.01 \\
\hline 3 & $\begin{array}{l}\text { The cash and marketable securities are maintained at a } \\
\text { higher level than the current liabilities }\end{array}$ & 0 & 8.5 & 23.9 & 49.3 & 18.3 & 3.77 \\
\hline 4 & The liquidity ratios are maintained at optimal levels & 1.4 & 7.0 & 12.7 & 56.3 & 22.5 & 3.92 \\
\hline 5 & The firm always prepares cash budgets & 2.8 & 8.5 & 0 & 53.5 & 35.2 & 4.10 \\
\hline 6 & $\begin{array}{l}\text { The firm is aided by cash flow projections in financial } \\
\text { planning }\end{array}$ & 0 & 1.4 & 12.7 & 57.7 & 28.2 & 4.13 \\
\hline 7 & The firm has an optimum cash balance policy & 1.4 & 11.3 & 12.7 & 50.7 & 23.9 & 3.84 \\
\hline 8 & $\begin{array}{l}\text { The firm regularly assesses the optimum and minimum } \\
\text { levels of liquidity }\end{array}$ & 1.4 & 4.2 & 11.3 & 64.8 & 18.3 & 3.94 \\
\hline & Average & $\mathbf{0 . 8 8}$ & $\mathbf{6 . 8 8}$ & $\mathbf{1 0 . 7 4}$ & $\mathbf{5 4 . 2 1}$ & $\mathbf{2 7 . 2 9}$ & $\mathbf{4 . 0 0}$ \\
\hline
\end{tabular}

Key: 1 = Strongly Disagree, 2 = Disagree, 3 = Neutral, 4 = Agree, 5 = Strongly Agree

The mean score of all the responses was 4.00 on a scale of one to five. This shows that there were more respondents who agreed with the statements in support of liquidity management practices having an influence on profitability. This indicates that firms are holding a lot of liquid cash and therefore they cannot maximize their profit. At the same time the firms are liquid enough and therefore there is no likelihood of the firms going bankrupt. High liquidity level means that the firms are putting their resources in liquid or unproductive assets and this means that the firms cannot maximize their profits. Bagchi and Khamrui (2012) assert that as firms increase the level of liquidity the profitability of the firm declines. There is a negative relationship between liquidity management practices and profitability. When liquidity level is high, it is a good picture about the firm's ability to generate cash and pay short term and long term debts as they fall due and at the same time the profitability level comes down (Award \& Al-Ewesat, 2012).

A correlation coefficient statistic that describes the degree of linear association between liquidity management practices and profitability was determined. Table 2 indicates that there is a positive significant linear relationship between liquidity management practices and profitability of manufacturing firms in Kenya. This relationship has been illustrated by correlation coefficient of 0.711 at 0.01 significant level. This implies that there is a positive and significant relationship between liquidity management practices and profitability of manufacturing firms in Kenya. This conforms with the results of the study carried out by Amalendu and Sri (2011) that found that there is a positive relationship between current ratio and absolute liquidity ratio with profitability. The positive relationship between liquidity management practices and profitability suggests that managers of manufacturing firms are able to handle and manage cash effectively. Through proper management of cash, the managers are able to create high profits for their companies.

Table 2: Correlation of Liquidity Management Practices and Profitability

\begin{tabular}{|l|l|l|l|}
\hline \multirow{4}{*}{ Profitability } & & Profitability & Liquidity Management Practices \\
\cline { 2 - 4 } & Pearson Correlation & 1 & $.711^{* *}$ \\
\cline { 2 - 4 } & Sig. (2-tailed) & & .000 \\
\cline { 2 - 4 } & $\mathrm{N}$ & 71 & 71 \\
\hline \multirow{2}{*}{$\begin{array}{l}\text { Liquidity Management } \\
\text { Prices }\end{array}$} & Pearson Correlation & $.711^{* *}$ & 1 \\
\cline { 2 - 4 } & Sig. (2-tailed) & .000 & \\
\cline { 2 - 4 } & $\mathrm{N}$ & 71 & 71 \\
\hline **. Correlation is significant at the 0.01 level (2-tailed). & \\
\hline
\end{tabular}

Regression analysis was conducted to determine the amount of variation in profitability explained by liquidity management practices. The calculated $\mathrm{R}-$ value was $0.711 . \mathrm{R}^{2}$ value $=0.5055$ which means that $50.55 \%$ of the corresponding variation in profitability can be explained by change in liquidity management practices. The rest $49.45 \%$ can be explained by other factors that are not in the model. The results of the analysis are shown in table 3.

Table 3: Model Summary of Liquidity Management Practices

\begin{tabular}{|l|l|l|l|}
\hline R & R Square & Adjusted R Square & Std. Error of the Estimate \\
\hline .711 & .506 & .491 & 3.88568 \\
\hline
\end{tabular}

A one way analysis of variance (ANOVA) whose results formed a basis for tests of significance was used. The ANOVA for the linear model presented in table 4 of liquidity management practices and profitability has an $\mathrm{F}$ value $=90.677$ which is significant with $\mathrm{p}$-value $=0.000<0.05$ meaning that the overall model is significant in the prediction of profitability in manufacturing firms in Kenya. We therefore reject the null 
hypothesis that liquidity management practices do not have any influence on profitability of manufacturing firms in Kenya and confirm indeed that there is a positive and significant influence of liquidity management practices on profitability of manufacturing firms in Kenya.

Table 4: ANOVA for Liquidity Management Practices and Profitability

\begin{tabular}{|l|l|l|l|c|c|c|}
\hline \multicolumn{2}{|c|}{} & Sum of Squares & df & Mean Square & F & Sig. \\
\hline \multirow{2}{*}{} & Regression & 1384.553 & 1 & 1384.553 & 90.677 & .000 \\
\cline { 2 - 7 } & Residual & 1053.558 & 69 & 15.269 & & \\
\cline { 2 - 7 } & Total & 2438.111 & 70 & & & \\
\hline
\end{tabular}

Analysis of the regression model coefficients is shown in table 5. From table 5 there is a positive beta co-efficient of 0.912 as indicated by the co-efficient matrix with a p-value $=0.000<0.05$ and a constant of 3.145 with a p-value $=0.151>0.05$. Therefore, the constant does not contribute significantly to the model and it is not different from zero. However, liquidity management practices contribute significantly to the model. Therefore, the model can provide the information needed to predict profitability from liquidity management practices. The regression equation is presented as follows: $\mathrm{Y}=0.912 \mathrm{X}+\varepsilon$ Where $\mathrm{Y}$ is the Profitability, $\mathrm{X}$ is the liquidity management practices and $\varepsilon$ is the error term

Table 5: Prediction of Profitability from Liquidity Management Practices

\begin{tabular}{|l|l|l|l|l|l|}
\hline \multicolumn{2}{|c|}{} & \multicolumn{2}{|c|}{ Coefficients } & \multirow{2}{*}{ Sig. } \\
\cline { 2 - 5 } \multicolumn{2}{|c|}{} & B & Std. Error & & \\
\hline \multirow{2}{*}{ (Constant) } & 3.145 & 2.248 & 1.399 & .151 \\
\cline { 2 - 5 } & Liquidity Management Practices & .912 & .094 & 9.702 & .000 \\
\hline \multicolumn{2}{|l}{} & & \\
\hline
\end{tabular}

\section{Conclusion And Recommendations}

Firms should invest the excess cash they hold to productive assets. This ensures that firms are able to maximize their profits. The Baumol cash model shows that a firm incurs an opportunity cost by holding cash. This opportunity cost increases with along with the cash level. This further shows that when a firm holds a lot of cash, it cannot be able to maximize its profit. According to the Miller - Orr model of cash management, a firm must set a lower cash level, optimal cash return level and the upper limit. Cash should never be allowed to go beyond the upper limit or below the lower limit. The results of the study show that the firms hold a lot of cash. This is an indication that the manufacturing firms in Kenya have not established their optimal cash target, lower and upper cash limits. This further shows that the firms are not able to maximize their profits. Thus, the finance managers should establish optimal cash targets, lower and upper cash limits in their firms. This will ensure that firms hold neither too low nor too high cash levels. They should invest excess cash in productive assets. This will ensure that firms do not hold excessive cash at the expense of increased fixed assets that are able of improving profitability.

\section{References}

[1]. Afza, T., \& Nazir, M. S. (2011). Working Capital Management Efficiency of Cement Sector of Pakistan. Journal ofEconomics and Behavioral Studies 2 (5), 223-235.

[2]. Amalendu, B. I. \& Sri, B. B. (2011). Importance of Liquidity Management and Profitability. Asian Journal of Business Management, 3 (2), 108-117

[3]. Atrill, P. (2006). Financial Management for Decision Makers. New York: Prentice Hall.

[4]. Award, I. M. \& Al-Ewesat, A. R. (2012). Toward Efficient Management of Working Capital: The Case of Palestinian Exchange. Journal of Applied Finance and Banking, 2 (1), 225 - 246

[5]. Bagchi, B. \& Khamrui, B. (2012). Relationship between Working Capital Management and Profitability: A Study of Selected FMCG Companies in India. Business and Economics Journal, 60, 1-11.

[6]. Cornett, M., M., Adair, T. A. \& Nofsinger, J. (2009). "Finance: Applications and Theory". New York: McGraw-Hill / Irwin.

[7]. Eljelly, A. (2004). "Liquidity-Profitability Tradeoff: An Empirical Investigation in an Emerging Market". International Journal of Commerce \& Management, 14 (2), 8-61.

[8]. Kotut, P. K. (2003). Working Capital Management Practices by Kenyan Firms: A case of Firms Listed in NSE. Unpublished MBA Project, Egerton University.

[9]. Kwame, K. (2007). Working Capital Management Practices of Small Firms in the Asharti Region of Ghana. Retrieved September 15,2013 from http://www.ssrn.com

[10]. Naser, K., Nuseibel, R. \& Al-Hadeya, A. (2013). Working Capital Management and Financial Performance on Manufacturing Sector in Sri Lanka. European Journal of Business Management, 4 (15), 23 - 30.

[11]. Nyabwanga, R. N., Ojera, P., Lumumba, P., Odondo, A. J. \& Otieno, S. (2012). Effects of WorkingCapital Management Practices on Financial Performance: A Study of Small Scale Enterprises in Kisii South District, Kenya. Africa Journal of Management, 6 (18), $5807-5817$.

[12]. Nyabwanga, R. N., Ojera, P., Otieno, S. \& Nyakundi, F. N. (2013). An Empirical Analysis of the Liquidity, Solvency and Financial Health of Small and Medium Sized Enterprises in Kisii Municipality, Kenya. EuropeanJournalofBusiness and Management, 5 (8), $1-15$.

[13]. O’Donnel \& Goldberger, M. (1964). “Accountants Financial Administration”. New Delhi: Prentice Hall of India Private Ltd. 
[14]. Opler, T., Pinkowitz, L., Stulz, R. \& Williamson, R. (1999). The Determinants and Implications of Corporate Cash Holdings. Journal of Financial Economics, 52, 3 - 46

[15]. Padachi, K. (2006). "Trends in Working Capital Management”. International Review of Business Research Papers, 2 (2), 45 - 58.

[16]. Pandey, I. M. (2008). "Financial Management", $10^{\text {th }}$ Edition. New Delhi: Vikas Publishing House Pvt. Limited.

[17]. Radhika, G. \& Azhagaiah, R. (2012). Impact of Working Capital Management on Profitability: Evidence from Sugar Industry in India. International Journal of Research in Computer Application and Management, 2 (1), 107 - 113.

[18]. Raheman, A \& Nazr, M. (2007). "Working Capital Management and Profitability - Case of Pakistan Firms". International Review of Business Research Papers, 3 (1), 279 - 300.

[19]. Ross, S., Westerfield, R., Jaffe, J. \& Jordan, B. (2008). Modern Financial Management. New York: McGraw - Hill.

[20]. Saleemi N. A. (1993). Business Finance Simplified. Nairobi: Saleemi Publications Limited

[21]. Sebastian, G. (2010). A Theory of Corporate Financial Decisions with Liquidity and Solvency Concerns. Journal of Financial Economics, 99, 365 - 384

[22]. Singh, J. P. \& Pandey, I. M. (2008). Impact of Working Capital Management on the Profitability of Hindalco Industries Limited. Icfai University Journal of Financial Economics, 6 (4), 62 - 72

[23]. Smith, M \& Begemann, E. (1997). "Measuring Association between Working Capital and Return on Investment". South Africa Journal of Business Management, 28 (1), $43-52$

[24]. Wood, F. \& Sangster, A. (1999). Business Accounting 2, $8^{\text {th }}$ Edition. London: Financial Times Pitman Publishing Limited 